\title{
Arctic Indigenous Societal Secu- rity at COP21: The Divergence of Security Discourse and Instru- ments in Climate Negotiations
}

Victoria Herrmann, PhD Candidate, Scott Polar Research Institute, University of Cambridge

This article explores the gap between Arctic societal security discourse and tangible climate change commitments to Arctic Indigenous peoples in UN climate negotiations. The author argues that the space for and use of Arctic societal security discourses at COP21 are not matched with climate commitments. Thus, the resulting global policy initiatives to support adaptation and mitigation in the North do not adequately support the security of current cultural practices and heritage in the Arctic. Empowering native culture of the North as a reason for acting on climate, but not empowering its security through tangible financial, legal, or technical commitments creates a post-colonial inequality in power in cultural security discourses and commitments.

On December $8^{\text {th }}, 2015$ seven women from Alaska and Greenland mounted a stage in the Indigenous Pavilion of the $21^{\text {st }}$ UN Climate Change Summit (COP21) to share songs, dances, and culture of their homeland (Kaljur 2015). They were in Paris, amongst a crowd of 40,000 people, to advocate for strong global action on climate change to save the Arctic from some of its most dramatic impacts (O'Rouke 2015). December $8^{\text {th }}$ had been named Arctic Day at the Conference - a day where space and time were dedicated to Saami and Inuit leaders to celebrate the cultures of the Arctic and caution delegates about the needs for preserving it in a rapidly warming world. Throughout the day, representatives from across the region shared the cultural heritage at risk from climate change. Sami singer Sofia Jannok performed and spoke of climate change against a backdrop that read "WE ARE STILL HERE," followed by a traditional dance performance by the Uummannaq Children. Later that evening, Elle Márjá Eira, an artist, filmmaker, singer, and reindeer herder from Finnmark, sung We Speak Earth. Altogether, the aim of Arctic Day at COP21 was clear: to show the world the rich heritage of the circumpolar north that stands to be lost 
if nothing is done to reduce global warming. "This is not a textbook for us," Cathy Towtongie, President of Nunavut Tunngavik warns the crowd. "This is our way of life" (Kaljur 2015).

Four days later, the world listened. The Paris Agreement, the product of two decades of work by members of the UN Framework Convention on Climate Change, set countries on a path to hold the increase in global average temperature to well below 2 degrees Celsius, and to pursue efforts to limit the temperature increase to 1.5 degrees, recognizing that this would significantly reduce the risks and impacts of climate change (UNFCCC 2015). To accomplish this, Paris created the foundation for a consistent flow of finances to help developing and least developed countries lower greenhouse gas emissions while simultaneously growing their economies. Beyond mitigation, the Agreement also envisioned a world where ample financial and technical resources would be made available to increase resiliency and augment adaptation efforts on the front lines of climate change. But while this global target to reduce greenhouse gas emissions ensures a reduction in the severity of future climate impacts in the Arctic, the Agreement makes no mention of the region directly, nor of the consequences happening today that can no longer be avoided. "[The agreement] was historic, yes," said Okalik Eegeesiak, Chair of the Inuit Circumpolar Council (ICC) to Radio Canada International in the days after returning from Paris. "[But] Inuit and Saami peoples wanted to have more recognition and respect for Arctic peoples," she said in a phone interview. "There is some mention of indigenous peoples and our rights and our role in climate change [issues] but there isn't much commitment to work with us" (Quinn 2015).

In UN climate change conferences, there exists a disconnect between the space for and use of Arctic cultural heritage as a catalyst for action and parallel international legal and financial support for climate adaptation and mitigation in the North. This article aims to unpack the gap between creating a space for societal security discourse and producing tangible climate commitments to Arctic Indigenous peoples in UN climate negotiations. After a brief introduction to its foundational scholarship, the article first surveys and explores visual and textual narratives pertaining to Arctic heritage at COP2 1 focusing on regional Indigenous political organizations and representatives. The narrative analysed emerges at the nexus of climate and culture, and contends both that societal security is to maintain Arctic indigenous culture in its traditional state and that societal security is to protect indigenous culture from harm or destruction while allowing it to live, change and develop in its own accord to assist with climate mitigation and adaptation actions. The article then turns to the resulting Paris Agreement and Paris Road Map to survey specific legal, financial, and policy support mechanisms for Arctic Indigenous peoples. The article will argue that the space for and use of Arctic Indigenous societal security discourses at COP21 are uneven with the resulting global policy initiatives, and do not adequately support the security of current cultural practices and heritage in the Arctic. It contends that empowering native culture of the North as a reason for acting on climate, but not empowering its security through tangible financial, legal, or technical commitments creates a 
post-colonial inequality in power in societal security discourses and commitments. Overall, the article aims to fill a gap in current scholarship on the nexus of security, Arctic identity, and climate change in order to better understand the interaction of societal security and scales of identity at UN climate change negotiations.

\section{Conceptual Framework of Societal Security and The Arctic Citizen}

Of all the dimensions of the recent model of 'comprehensive' security, societal security is perhaps the softest and most elusive of its iterations. In the Copenhagen School which Wæver founded and wherein the concpept of societal security finds its origin, security is not a static concept but rather a changing phenomenon influenced by international developments in conflict, economy, identity, and politics, among others. Societal security is no exception to this. It is complex and ambiguous, in no small part because it is dynamic and depends on so many factors. Societal security is "the defence of an identity against a perceived threat, or more precisely, the defence of a community against a perceived threat to its identity" (Wæver 2008, 581). Here, the identity of the community, rather than the sovereignty of the state, is the value, or referent object, that is being protected. This deepening and complementation of the idea of security to include issues of identity, and in turn culture and heritage, necessitates a brief unfolding of the concept of identity, how it relates to security, and what the nexus of identity and security means in the multi-state and multi-national space of the Arctic. Identity can be understood in relation to Benedict Anderson's seminal works on imagined communities and nations, where nations are a socially constructed community imagined by the people who perceive themselves as part of that group (Anderson 1991). Here, the community and its shared identity is imagined because "members of the nation will never know most of their fellow-members, meet them, or even hear of them, yet in the minds of each lives the image of their communion" (Anderson 1991, 49). Individuals construct a stretchable net of kinship that allows for, and is built upon, a shared identity, history, and culture. As Gellner argues, "Nationalism is not the awakening of nations to self-consciousness: it invents nations where they do not exist" (Gellner 2008). ${ }^{1}$

It is within this space of nation, of constructed shared identities, that the conceptualization of the 'Arctic Citizen' is born in the global climate change science and risk discourse. In Marybeth Long Martello's Global Change Science and the Arctic Citizen, she proposes that climate change has given birth to the development of a new type of

\footnotetext{
${ }^{1}$ Societal security and the use of identity, as opposed to state sovereignty, as the referent object does have its opponents. Early on, scholar Bill McSweeney $(1998,137)$ argued that identity does not have an empirical base upon which to lean, and is either an act, whereupon identity relates to the ability of individuals to uphold the narrative about them as a collective self, or a structure, wherein identity relates to the story from which the individuals attempt to build an identity. In this reading, identity is understood as a process and not as an object to be secured. In response, Wæver and Buzan (reference is lacking) have attempted to demonstrate that social communities defined in terms of identity can become a reference object in some events of securitization in which the value that is being protected is not the sovereignty of state but rather the identity of community.
} 
political, identity-based actor in the North (Martello 2004). Martello proposes that by weaving together generational knowledge and social agenda setting across tribes, Indigenous groups have constructed and adopted a new imagined identity, and in turn empowered this identity as an emerging regional policy community. This type of identity can be seen as a combination of the nation (an imagined community) as defined by possessing compact, well-defined territories at their homeland, a land that acts as a repository of historic memories and associations, the place where 'our' sages and heroes lived and fought, and nation as predominately defined by ethnicity. Adopting the Societal Security approach of the Copenhagen School, Arctic Indigenous organizations and community representatives can come to define their own identity independent of (and at times in opposition to) the political state within which they are located (Wæver 1993, 23). Indeed, the legitimacy of the state is neither exclusively nor necessarily founded on social identity, but Arctic Indigenous actors can create currency in the international arena through establishing an independent social identity. Closely linked to constructivism and developed around Barry Buzan and Ole Wæver's conceptualization of security, societal security is "about the large, self-sustaining identity groups" of the collective identities of societies which share a common "we-feeling" (Buzan et al. 1998, 119). Here, the state is not the focal action in the international security framework, but instead a group of people who share a common identity. As Buzan explains, "Society is about identity, the selfconception of communities and of individuals identifying themselves as members of a community. These identities are distinct from, although often entangled with, the explicitly political organizations concerned with government" (Buzan et al. 1998, 119). Here, the Arctic Citizen, the imagined community of the North and its shared identity, are built on the idea that the circumpolar north has been their homeland since time immemorial, where legendary heroes like Kiviuq, an eternal Inuit wanderer, lived and travelled. Their identity, and in turn societal security, is not tied to the Western concept of a state with hard borders and a sovereignty to be secured. Rather, the Arctic Citizen's identity is tied to the landscapes of the Arctic, indigenousness, and the ethnic distinction they possess as being direct descendants from the original inhabitants of the North. In the societal security framework, this identity is the referent object that is being secured, not any one Arctic state.

As climate science regionalizes the Arctic, it has simultaneously underwritten an Arctic identity centred on the notion that its peoples comprise an at-risk community. Science, and in turn the policy community, treat the Arctic as a single unit under pressure from a variety of global forces. In analysing how native peoples construct their own political agency through different strategies to further their own political interests in the Arctic, Monica Tennberg furthers Martello's work to find that Indigenous political agency is based on multiple forms of power and activist leaders' ability to change the structure of power relations to create space for their own political agency (Tennberg 2010). Through the emergence of a regional identity, the voice of this new citizen has been recognized as an important part of knowledge creation of socio-ecological changes 
of the region's systems, providing a certain level of agency on the part of the Arctic Citizen that allows their voice to be heard through regional Indigenous organizations. Rather than people being passive victims, as they had been before, the Arctic Climate Impact Assessment (ACIA) depicts them as adaptive beings and holders of knowledge, so that they come to embody a dual identity of victim and expert. This has resulted in changing approaches to knowledge formation, mapmaking, and the quantification of climate change, including ACIA successfully privileging the Indigenous experience in the north by including new approaches to knowledge production, detailed accounts of Indigenous communities, provision of heightened public visibility, and, consequently, strengthened their agency in climate change issues. (Martello 2008).

Societal security in the Arctic relates to the capabilities of the "Arctic Citizen" to "preserve its essential characteristics in the face of variable circumstances and despite the potential or actual threat" (Hough 2004, 106). Societal insecurity, then, exists when communities of any kind identify a threat to their survival as a community (Wæver 2008, 582). In societal security theoretical scholarship, threats are either horizontal competition, such as migrations, or vertical competitions, such as integrations and secessions (Wæver 2008, 583). The vast majority of societal security scholarship focuses on these two types of threats in ethnic conflicts, minority rights, immigration, regionalism, separatism, and anti-Western nationalism and rhetoric. Significantly less developed is the notion that climate change poses a threat to societal security. When climate change is addressed in the Copenhagen School, it is almost entirely within the environmental security strand. But environmental threats to societies can occur, especially when identity is tied to a particular territory and culture is adapted to a way of life that is strongly conditioned by its natural surroundings. Threats to the environment, whether they be deforestation, pollution, or climate change, can endanger the existence of that culture, and in turn the society to which it belongs (Roe 2010, 220). Of course, these dimensions cannot adequately address the issues of security separately; each of the sectors Wæver and Buzan lay out affect each other in real life, and climate change, like many threats, involve a combination of them. If we are to understand climate change as a threat, or at least a threat multiplier, to other strands - economic, ecological, political, and military - then we must also untangle climate change as a threat to societal security.

A subsidence-based way of life that is close to traditional land is central to Northern Indigenous groups' cultural identities. Arctic society's identity focuses on an intimate dependence on traditional methods for hunting and fishing, housing, sharing of food, and travel on snow and ice, among many others. This provides a long-established spiritual and cultural communal existence through an intimate relationship with their surroundings. Even the development of northern indigenous languages is intimately connected with ice, land, sky, and wildlife. But as climate and geophysical changes occur with warmer temperatures, performing basic tasks vital for both food and cultural development, like hunting trips, are becoming not only challenging, but also dangerous with thinner, less stable ice. Some traditional travel routes to camp sites, neighbouring communities, and hunting and fishing areas have become unreachable. A 
changing climate also has implications for the passage of traditional knowledge from one generation to the next, particularly their weather predicting skills. Their weather and climate-related knowledge of hunting conditions from cloud and wind pattern observations do not fit with today's changing climate. Many villages across the North are heavily reliant on subsidence lifestyle activities based around Arctic waters, including the Chukchi Sea, Baffin Bay, and the Northwest Passage. However, the massive thinning of ice sheets and glaciers have negatively impacted the abundance and distribution of Arctic wildlife species, including the ringed seal, salmon, walruses, and caribou, many of which will be pushed to extinction by 2070-2090 (Watt-Cloutier 2004). In addition to less access to wildlife and flora like berries for collection, changes in see ice thickness and distribution, permafrost conditions, and extreme weather events also increase risks for personal injury. Food storage is also being undermined by climate change. Traditionally, outdoor meat caches were used to keep community food fresh and preserved in the cold. Today, these traditional storage methods are no longer viable, as higher temperatures spoil communal preserves. There is also the potential that climate change could increase human exposure to contaminants like organic pollutants, heavy metals, and radionuclides through shifting air and water currents.

Across the Arctic region, Indigenous communities have effectively bolstered their capacity to conserve native languages, diets, and traditions in spite of many changing conditions. But melting sea ice, shoreline erosion, and forest fires are endangering societal security by threatening the continuation of a culture that has survived and thrived for millennia. If a society loses its unique identity, it cannot survive as a society. There are many actors involved in securing Indigenous cultural heritage in the face of a changing climate, including the United Nations, national governments, and non-governmental organizations. The most vocal and effective of these actors are Arctic Indigenous organizations and Arctic communities themselves. The section to follow uses Arctic Day at COP21 as a case study to examine the types of narratives constructed by and about the Arctic Citizen at UN climate negotiations. It then turns to a textual analysis of the Paris Agreement and auxiliary texts to survey how and to what extent the Arctic Citizen is included in the resulting documents. The article finally returns to the conceptual framework laid out here to analyse how the Paris Agreement addresses, or does not address, societal security of the Arctic Citizen.

\section{The Arctic Citizen at COP21}

The use of Arctic visuals as the iconic imagery and symbolism of climate change has been well documented (Manzo 2010). Surveys show that circumpolar visual imagery like polar bears and retreating ice act as emotional anchors or referents to an otherwise abstract phenomenon, and as such are widely circulated and reproduced. In the words of Vidal, "It's the age of the melt... when the stranded polar bear becomes the symbol of the times." (Vidal 2008). The symbolism of the Arctic at COP21 was no exception to this. "Ice Watch' at the Place de la Republique invited visitors to walk around blocks of ice from 
Greenland, watching as the natural sculptures melted before their very eyes. The installation, by Greenlandic geologist Minik Rosing and Icelandic-Danish artist Olafur Eliasson, was meant to "make the climate change we are facing tangible" and 'inspire shared commitment to take climate action" (Walker 2015). Further down the road, Greenpeace's three-tone mechanical polar bear, Aurora, marched towards Le Bourget Conference Center. While these more recognizable visual narratives that exhibited the power of the polar bear icon to represent climate change in the minds of the public were present, a parallel narrative - one that was both complementary to and in contention with the polar bear narrative - was also employed in Paris.

In effect, the intent of COP21 Arctic Day was to provide an alternative visual narrative of the Arctic in a rapidly changing climate - a narrative defined not by polar bears and ice but by the richness of the human experience in the circumpolar north. In the words of Inuit Circumpolar Chair Okalik Eegeesiak as she presented in the Indigenous Pavilion on December 8th, "Stop using the polar bear as an icon for climate change. This does not help us address the very real human dimension. Same with the seals" (Kaljur 2015). But beyond the reorienting of narratives from mega fauna to humans, if considered within the comprehensive security framework provided by the Copenhagen School, COP21's Arctic Day's intent and rhetoric were rooted in notions of societal security. As defined by Buzan and Wæver, society itself is "about identity, the self-conception of communities and of individuals identifying themselves as members of a community" (Buzan et al. 1998, 119). In a full day of programming, Arctic Indigenous representatives at COP21 presented themselves as a single, pan-regional society through cultural performances and informational presentations. The structure of the event was built upon a twofold societal security foundation: (1) that the Arctic Citizen and Arctic society has a resilient ability to persist in its essential character in the face of political, economic, and colonial/post-colonial threats; and (2) that the Arctic Citizen and Arctic society is unable to persist in its essential character under changing ecological conditions and threats of a rapidly changing homeland that are exacerbated by land rights and imperialist policies.

Arctic Day was the production of both a visual and oral narratives of a culture at risk as a means to construct an imagined community, as seen through its schedule:

11.00-12.05 Film Screening: "Last Yoik of the Saami Forest"

12.10-14.10 Film Screening: "Inuk"

14.15-15.45 Film Forum by Saami Film Institute: 7 Saami Stories \& Stoerre Vaerie

14.15-15.45 Joiking Workshop - We speak Earth by Áslat Holmberg

15.45-15.50 Dance performance by Uummannaq Children

16.00-16.15 Ted X talk on Climate Change by Sofia Jannok

16.15-17.45 Panel Session: Climate Knowledge and Solutions from

Arctic Voices With Okalik Eegeesiak, Aili Keskitalo, Cathy Towtongie, Reggie Joule and Maatalii Okalik

17.45-18.45 Saami concert by Elle Márjá Eira 
Notably, Arctic Day's narrative is an evolution of external threats to Arctic Indigenous identity and culture that begins with state discrimination and post-colonial legacies that are then woven into current insecurities of a changing climate for Arctic society. The opening film, "Last Yoik of the Saami Forest," chronicles the logging damage that has taken place in the forests of Finnish Lapland over the past 50 years (Documentary Educational Resources). The Northern old growth forests therein are essential to Saami reindeer herding and their traditional way of life, but have been severely deforested by the state-owned logging company Metsahalltus. The consequence put forth in the film is the Saami fears that it will not be able to live as itself with its distinctive characteristics and dynamics once its landscapes are changed. While this threat to societal security is not one put forth by Buzan in his work - migration, horizontal competition, or vertical competition to a society's culture and cohesion ${ }^{2}$ changing the landscapes provides the same threat to cultural heritage and identity. The focus on environmental degradation and its effects on identity offers a transition to climate change as a threat to the survival of the Arctic community as a cohesive unit. The film Inuk then acts as the bridge between environmental and climatic threats to identity. Inuk is a coming-of-age story of 16-year old Gaaba Petersen, who was raised in Nuuk and sent to Uummannaq Orphanage, a foster home in the North, after his parents are unable to care for him due to alcoholism (Inuk 2014). While in the North, Gaaba is sent to a bear hunter to learn the wisdom of his people, and in this journey into manhood where seal hunts replace video games, he encounters the effects of global warming.

For the remainder of the day, the cultural richness of the Arctic Citizen's identity and climate change as a threat to that societal security are interlaced through dance performances by Uummannaq Children, talks on climate change in the North, vocal performances that 'speak for the earth,' and conversations about climate knowledge and solutions to a rapidly changing landscape. Arctic Day buttressed two concepts. First, that societal security in the Arctic, as theorized generally by Wæver, is not tied to a state territory. Rather, the large-scale collective identity of Indigenous peoples to the circumpolar north function independent of the state. Together, Inuit leaders from across the region drafted and presented a joint declaration on climate change in the Arctic - "to send a united message to the world, to recognize and support the special challenges that climate change poses for Arctic peoples and the right to development in the Arctic," noted then Minister of Labor, Finance, Ministerial Resources, and Foreign Affairs Vittus Qujaukitsoq on December $8^{\text {th }}$. "Our joint Inuit voice and our traditional know-how from across the Arctic should be heard and included in international policy-making. Most importantly, Arctic indigenous peoples have to be ensured equal access to the right to development. Indigenous peoples' rights and interests must be included in the COP21 outcome document" (Walker 2015; Governments of Nunavut and Greenland, and Inuit Circumpolar Council 2015).

\footnotetext{
${ }^{2}$ To be sure, Arctic Indigenous communities have faced these external threats to their identity and culture. As described by Inuit Circumpolar Council Chair Okalik Eegeesiak at COP21 "Despite all odds, we are still here."
} 
Perhaps the societal insecurity brought about by a changing climate is captured in an interview that lle Márjá Eira, the final performer of Arctic Day, did with Snowriders International while at COP21. On camera and in her performance on the evening of December $8^{\text {th }}$, she spoke of how a warmer world is impacting her and her family's identity in the small Saami village.
"My family works with reindeers and climate changes is affecting us personally because if the snow disappears then our way of living disappears. It's our tradition, and we're gonna have a lot of prob- lems herding the reindeer, and the reindeers will also struggle. And I'm afraid that if the snow disappears then will the Saami people also disappear, our traditions and our language? That's why I'm here using my voice, by showing my films, talking to people, and also through music. It's important to use your voice and tell about us, even when we are not invited to the grand conference" (Snowrid- ers International 2015).

1le Márjá Eira presents her and her family's identity as a part of the collective Arctic societal identity on a lower scale. Identities are inherently multi-layered based on an individual's lived and inherited experiences. Gender, economic class, marital status, and religion are just a few of the many layers an individual can perform within their identity, while scales, from the identity of a resident of a specific village to Arctic Citizen to Indigenous, all the way up to a member of humankind, add yet another layer to identity. Each of these different scales of identity are multiple, overlapping, and at time in contention with one another (Tsing 2000). The identity narratives and societal insecurities presented here are no different. The Arctic Citizen identity was the primary identity proposed, but it was inevitably combined with other scales of identity that were being practiced, and evaded. Saami, Inuit, Canadian, Greenlandic, American, Alaska, European, Indigenous, and the list goes on. Arctic Day at COP21 transcended these multiple and contested scales of identities, to present a singular, shared narrative of a threatened, culturally-unique in a full day of dance, film screenings, songs, and speakers on at-risk cultural heritage and social safety nets.

Nonetheless, the space for Arctic Indigenous actors to present societal insecurity at COP21 did not translate into textual legal and financial commitments to security for the Arctic Citizen. This is not to say that there have not been other significant advances in the recognition of Arctic Indigenous agency and voices. The Permanent Participants of the Arctic Council and scientific research reports like the Arctic Climate Impact Assessment hold testament to this. However, the final text of the Paris Agreement does not make mention of the Arctic region or their insecurities nor do other parallel documents like the Adaptation Fund or the Warsaw International Mechanism for Loss and Damage from the Effects of Climate Change. While the Arctic Citizen was present and active discursively in Paris, they were not represented in its result. 


\section{The Gap between Physical and Textual Spaces at COP21}

Paris was a high-level negotiation that established broad strategies for mitigating greenhouse gas emissions and adapting to the consequences, historic emissions have generated through the Paris Agreement. The development of the Paris Agreement since 2015 has focused on creating a practical plan for climate action by answering the question of how to actually limit temperatures to "well below" two degrees; how governments of developed countries will concretely help those on the front lines of a rapidly changing environment; and what breakthrough innovations are needed to transform the global economy to be resilient, equitable, and carbon neutral. While the rules for the Paris Agreement's implementation are set to be finalized by 2018, with the next big climate policy milestone in 2020 when each country will put forward an enhanced national climate plan, the Paris Agreement itself and the roadmap to the rulebook provide a number of mechanisms to address societal security (Darby et al. 2016). These include climate finance, the adaptation fund, and the Warsaw International Mechanism on Loss and Damage.

Why are the narratives and space for discourses of Arctic Indigenous culture and identity at COP21 not paralleled in the resulting agreement? While there exists an acknowledgement and empowerment of Indigenous actors as knowledge-holders and contributors, current scholarship stops short of analysing the lack of legal and political instruments that might be employed to achieve the societal security advocated specifically by the 'Arctic Citizen.' Current scholarship offers two possibilities for the lack of tangible instruments to support Arctic Indigenous cultures in a changing climate. The first is the "slipperiness" or "softness" of the concept of culture itself, and therefore an inability to effectively secure something as dynamic and amorphous as culture (Forrest 2004). As noted by Scott Forrest at the Northern Research Forum in Yellowknife in 2004:

"The boundaries of culture are of course permeable and dynamic, which exacerbates the difficulty of "securing" them, particularly through legal protection. Once you define and prescribe what you want to protect, you create artificial permanence and inhibit the natural change that defines a living culture. Living cultures are at once persistent in that the course of the river is relatively unwavering, but at the same time the water moving through it is always in motion. The inherent tension between permanence and dynamic change lies at the heart of placing culture within the framework of security."

Because of this difficulty to articulate the concept of identity into a form where it can be effectively 'secured' through political and legal means, the pursuit of indigenous societal security has often been advanced under the guise of biodiversity, sustainability, and en- 
vironmental security. This has occurred by borrowing similar justifications and arguments from the biodiversity discourse, by promoting idealized images of indigenous peoples resource managers, and through strategic alliances between indigenous peoples and environmental NGOs. This grafting of science narratives onto cultural identity to foster political agency is a concept picked up by Michael Bravo in Voices from the Sea Ice. As Bravo explores how climate change narratives have shaped notions of Arctic Citizenship, he finds that the vocabulary of ecological risk, which enjoys widespread currency in political discussion about climate change, has constructed an Arctic Citizen that is visible but voiceless (Bravo 2009). He concludes that northern communities have largely embraced this new notion of citizenship in order to monopolize on the agency imbued in regional victims, but that these voices are often masked by the southern produced narratives themselves.

However, when these arguments are graphed onto the proceedings of the UNFCCC and COP21, they fall short of explaining why Arctic society is left insecure. Noneconomic assets of society - the shared historic sites and cultural heritage that buttress identity and societal cohesion - are secured in UNFCCC frameworks. For example, UNESCO, the UN organization responsible for coordinating international cooperation in education, science, culture, and communication, serves on the Adaptation Fund Board as a Multilateral Implementing Entity. The Adaptation Fund was created in 2001 (the last time the Conference of the Parties was in Marrakesh) to support adaptation projects in developing countries. It was originally tied to the soon-to-expire Kyoto Protocol, the last big international agreement linked to the UNFCCC that committed parties to binding emission reduction targets. Since its establishment, the Fund has financed \$358 million of mostly small-scale projects to help communities' adaptation to the effects of climate change we can no longer avoid (World Bank Ground 2016). Developing countries have largely applauded the Fund as a success, and in particular its direct access structure that allows accredited countries to manage their own projects. Such a structure allows developing countries to have a sense of ownership as the majority share of the Fund's governing board seats. The Adaptation Fund sought $\$ 80$ million to finance projects already in place ahead of the meeting in Marrakesh, which was fulfilled by European commitments. As a Multilateral Implementing Entity, the culture-based organization is able to serve "vulnerable countries by directly working with them to address their requests and needs, while collaborating and mobilizing the necessary resources and partners for effective local implementation on the ground" (UNESCO 2016).

In addition to UNESCO's participation in the Adaptation Fund, the Warsaw International Mechanism on Loss and Damage, associated with Climate Change Impacts' work on noneconomic loss and damage, also challenges the slippery argument of culture. In 2013, Parties of the Conference established the Warsaw Mechanism to promote the implementation of approaches to address loss and damage, including the non-economic losses like historic sites, cultural heritage, tradition, and identity (United Nations 2017). In its first two years, the Warsaw Mechanism established a number of expert groups, like that on non-economic losses, that are working to enhance data on and 
knowledge of losses associated with the adverse effects of climate change, and identify ways forward for reducing the risk of addressing losses with specific focus on potential impacts within regions. One of the most concrete actions to come out of COP22 in Marrakesh was the approval of a five-year work plan on loss and damage, to begin in 2017 under the Executive Committee of the Warsaw International Mechanism. Moving forward, this work plan will guide countries in formally addressing topics like slow-onset impacts of climate change, climate-induced migration, and non-economic losses and damage - including culture, historic sites, traditions, and identity (United Nations 2016).

However, none of these internationally-based climate change instruments can be used by Arctic Citizens. While other sub-societal identities are acknowledged within the Paris Agreement and auxiliary documents like the Warsaw International Mechanism, developed and developing societies based on the economic status of their state is the privileged identity scale at UNFCCC negotiations. The term 'Arctic' does not appear in the text of the Paris Agreement, and Indigenous peoples are only acknowledged twice for their particular vulnerabilities, knowledges, and rights, in its preamble and in Article 7.5. ${ }^{3}$ Neither of these references come with particular actions; rather, they are merely acknowledgements. By contrast, there are 49 references to developing and least developed countries with stronger language. For example, in Article 5, "Support shall be provided to developing country Parties for the implementation of this Article, in accordance with Articles 9, 10 and 11, recognizing that enhanced support for developing country Parties will allow for higher ambition in their actions."

The elusiveness of identity and culture as the foundational concepts upon which societal security rests are general difficulties when addressing insecurities; however, it is clear that non-economic assets and non-tangible losses have been considered in the UNFCCC and while drafting the Paris Agreement. A third explanation may illuminate an important addition to the framework of understanding Arctic societal security at COP21, namely, an explanation based on privileged scales of identity in UNFCCC negotiations and decision-making. The two examples of societal security, and specifically non-economic assets associated with societal identity, use the identity scale of the sovereign state to provide assistance. The Paris Agreement and the UNFCC generally divide the world

\footnotetext{
3“Acknowledging that climate change is a common concern of humankind, Parties should, when taking action to address climate change, respect, promote and consider their respective obligations on human rights, the right to health, the rights of indigenous peoples, local communities, migrants, children, persons with disabilities and people in vulnerable situations and the right to development, as well as gender equality, empowerment of women and intergenerational equity."
}

“Article 7.5. Parties acknowledge that adaptation action should follow a country-driven, gender-responsive, participatory and fully transparent approach, taking into consideration vulnerable groups, communities and ecosystems, and should be based on and guided by the best available science and, as appropriate, traditional knowledge, knowledge of indigenous peoples and local knowledge systems, with a view to integrating adaptation into relevant socioeconomic and environmental policies and actions, where appropriate." 
into developed and developing countries, wherein developed countries provide financial, technical, and political assistance in mitigation, adaptation, and damage efforts in developing states. There is a disadvantage to understanding climate change policy in this way for the societal insecurities of the Arctic Citizens, as it makes invisible the developing communities within developed states, those who are both on the front lines of rapid climate change and are at the periphery of both the political and financial geographies of their countries. Although the effects of climate change know no borders, international climate negotiations have long held an established, inelastic geopolitical map. Since the founding days of the Conference of the Parties, the world cartography of climate policy has been drawn into three blocs: the developed, the developing, and the least developed worlds. The founding document of the COPs, the UNFCCC, proposed at the 1992 Rio Earth Summit and ratified by 194 parties in 1994, called for "common but differentiated responsibilities and respective capabilities" to reduce country emissions" (United Nations 2016). Until COP21 in 2015, developing countries led by China argued that they should not be held to the same limits on emissions as developed countries because of historical emissions by developed countries and their own development needs. Because of historic inequalities and the persistence of extreme poverty in many developing countries, climate justice became tied to allowing developing economies to make a slower transition away from carbon-intensive, cheaper fuels while requiring developed countries to make deeper emission cuts first.

\section{Arctic Societal Security as a Missed Scale}

As the Paris Agreement and tangential meetings and negotiations focus on global transformations and vulnerabilities and finances support needs of developing countries, ecologically, socio-economically, and politically vulnerable communities in developed countries like the Arctic become obscured. But the Arctic is warming twice as fast as the rest of the globe from a process known as polar or Arctic amplification (ACIA 2005). And this amplified warming at the pole means that limiting global warming to 2 degrees Celsius will result in a 4 degree increase in the circumpolar north (Mooney and Samenow 2016). Arctic leaders at COP21 were aware of this privileging of developed/developing identity over the Arctic's regional or Indigenous societal identity within the texts. "We keep reminding our respective governments that Inuit, Saami and northern indigenous Peoples should be considered underdeveloped communities," Eegeesiak noted at Arctic Day. "We will be going after the funds that were announced as well" (Kaljur 2015). Nonetheless, in spite of statements like these, the text of the Paris Agreement still makes no tangible guarantees to the Arctic Citizen as a community entirely within developed states. Revisiting the definition of societal security, "the capacity of a society to conserve its specific character in spite of changing conditions and real or virtual threats" (Forrest 2004, 1), the Paris Agreement and UN programs related to COP21 do not provide Arctic society with the financial or technical resources to fulfil this capacity. The opportunities offered by the Adaptation Fund, the Warsaw International 
Mechanism, or the Paris Agreement deliver the financial means for societies in developing and least developed countries to preserve their essential characteristics in the face of climate change. The Arctic Citizen, however, is left a space to voice their needs for international agreements and programs to address Arctic societal security, but not any means to address their insecurities.

In the shadow of the US Presidential Election, the 22nd Conference of the Parties to the United Nations Framework Convention on Climate Change (UNFCCC) took place in November 2016. More commonly known as COP22, the conference brought country delegations from around the world to Marrakesh, Morocco, in an effort to move humanity forward in curbing global warming. Like COP21, COP22 failed to translate the discourse around Arctic societal insecurities into tangible commitments. There were two Arctic Days at COP22, one held at the Nordic Pavilion on November $12^{\text {th }}$, and one held at the US Pavilion titled The Melting Arctic - a glimpse into the future of global climate change, held as part of their Arctic Council 2015-2017 Chairmanship on November $11^{\text {th }}$. Both of these events highlighted the challenges of living in a rapidly changing North, though, importantly, neither featured Indigenous representation and neither focused on identity as the organizing concept. Each Arctic Day spoke to the threats global climate change brings to traditional Arctic cultures, historic livelihoods, and safety, with a focus on the physical impacts of climate change on communities. Scientists, policymakers, and researchers spoke about the insecurities climate change is bringing to Arctic communities. And yet, Marrakesh followed in COP21's footsteps in its privileging of state scales of identity over sub-national societies. With no specific legal, financial, or technical assistance from the UN, Arctic Citizens as a sub-national identity still face threats to their survival as a community as the region warms (Wæver 2008, 582).

Providing a space for Arctic Citizens to voice these security threats to society is important, but does not reify Arctic Indigenous society as an independent social agent endowed with the agency to have their sub-state identity as Arctic Citizens, within developed countries, to be acknowledged and protected in the negotiations themselves. This in turn, as argued by this article, leaves the Arctic Citizen unable to 'defend' their identity in the face of climate change through any of the available international climate policy or finance mechanisms. The UN Conference of the Parties Process will continue onward from COP22 long into the future. Delegates from Parties of the Paris Agreement will work to limit future greenhouse gas emissions and to safeguard the least abled amongst humanity to adapt to the already locked-in effects of a warming world. This article provides a foundation for understanding the interactions of societal security and scales of identity at UN climate change negotiations by examining what societal security is for the Arctic Citizen, where the Arctic fits into UN climate change negations, and what the ultimate texts reveal about the Arctic's inclusion in global action on climate change adaptation, mitigation, and loss and damage work. But this survey should serve as just that - an exploration upon which future research can build to understand, analyse, and 
ultimately address the gap between societal security rhetoric and climate action at the top of the world.

\section{Bibliography}

Althor, G., Watson, J.E. and Fuller, R.A. (2016). Global mismatch between greenhouse gas emissions and the burden of climate change. Nature: Scientific Reports, 6. Available at: www.nature.com/articles/srep20281_[Accessed Day Month Year]

ACIA Secretariat and Cooperative Institute for Arctic Research. (2005). Arctic Climate Impact Assessment. Cambridge: Cambridge University Press. Available at: www.acia.uaf.edu/pages/scientific.html [Accessed 19 June 2017.]

Bravo, M.T. (2009). Voices from the sea ice: the reception of climate impact narratives. Journal of Historical Geography, vol. 35(2), pp. 256-278.

Buzan, B., Wæver, O. and de Wilde, J. (1998). Security: a new framework for analysis. City Published: Lynne Rienner Publishers.

Center for American Progress. (2017). Talk Poverty: Alaska. talkpoverty.org. Available at: talkpoverty.org/state-year-report/alaska-2016-report/ [Accessed 2 January 2017].

Darby, M., Mathiesen, K., King, E., and Del Bello, L. (2016). COP22 Headlines: What Did Marrakesh Climate Summit Deliver?. Climatechangenews.com. 18 November. Available at: www.climatechangenews.com/2016/11/18/cop22-headlineswhat-did-marrakech-climate-summit-deliver/ [Accessed 10 January 2017].

Collins, A. (2016). Contemporary Security Studies. Oxford: Oxford University Press, p. 220.

Fantom, N., Khokhar, T., and Purdie, E. (2016). The 2016 Edition of World Development Indicators is Out: Three Features You Won't Want to Miss. The World Bank. Available at: blogs.worldbank.org/opendata/2016-edition-world-developmentindicators-out-three-features-you-won-t-want-miss [Accessed 10 January 2017].

Forrest, S. (2004). September. Indigenous identity as a strategy of cultural security. Presented at Northern Research Forum, Plenary on Security, September 18, 2004, Yellowknife, NWT.

Gellner, E., 2008. Nations and nationalism. Ithaca: Cornell University Press, p. 71.

Government of Nunavut and Greenland, and Inuit Circumpolar Council. (2015). Governments of Nunavut and Greenland, and Inuit Circumpolar Council issue joint statement on climate change. Nunavut Department of Executive and Intergovernmental Affairs. 8 December. Available at: http://gov.nu.ca/eia/news/governments-nunavut-andgreenland-and-inuit-circumpolar-council-issue-joint-statement. [Accessed 19 June 2017]. 
Hallengatte, S., Bangalore, M., Bonzanigo, L., Fay, M., Kane, T., Narloch, U., Rozenberg, J., Treguer, D., Vogt-Schlib, A. 2016). Shock Waves: Managing the Impacts of Climate Change on Poverty. The World Bank. Available at: openknowledge.worldbank.org/bitstream/handle/10986/22787/9781464806735.pdf [Accessed 2 January 2017].

Hersher, R. (2016). The Arctic Suicides: It's Not the Dark that Kills You. NPR. 21 April. Available at: www.npr.org/sections/goatsandsoda/2016/04/21/474847921/thearctic-suicides-its-not-the-dark-that-kills-you [Accessed 2 January 2017].

Inuk. (2010). [video]. Ann Andreasen, Mike Magidson, Marc Buriot, Sylvie Barbe. Accessible at: http://www.inuk-film.com/ [Accessed 7 August 2017].

Kaljur, L. (2015). Arctic Day at COP21. Artic Journalism. 10 December. Accessible at: http://arcticjournalism.com/arctic-day-at-cop-21/. [Accessed 20 January 2017].

Manzo, K. (2010). Beyond polar bears? Re-envisioning climate change. Meteorological Applications, vol. 17(2), pp. 196-208.

Martello, M.L. (2004). Global change science and the Arctic Citizen. Science \& Public Policy (SPP), vol. 31(2), pp. ??-??.

Martello, M.L. (2008). Arctic indigenous peoples as representations and representatives of climate change. Social Studies of Science, vol. 38(3), pp. 351-376.

Mooney, C. and Samenow, J. (2016). The North Pole Is an Insane 36 Degrees Warmer than Normal as Winter Descends. The Washington Post. Available at: www.washingtonpost.com/news/energy-environment/wp/2016/11/17/thenorth-pole-is-an-insane-36-degrees-warmer-than-normal-as-winter-descends/?utm_term=.f509bf50bb88 [Accessed 2 January 2017].

NOAA. (2016). Warmer Air and Sea, Declining Ice Continues to Trigger Arctic Change, National Oceanic and Atmospheric Administration. Available at: www.noaanews.noaa.gov/stories2015/121515-arctic-report-card-warmer-air-and-seadeclining-ice-continue-to-trigger-arctic-change.html [Accessed 2 January 2017].

Nunatsiaq News. (2016). Nunavut Unemployment Jumped to 15.4 percent in April. Nunatsiaq Online. 10 May. Accessible at: bit.ly/2lI6weG [Accessed 2 January 2017].

OECD. (2016). 2020 projections of Climate Finance towards the USD 100 billion goal: Technical Note. OECD Publishing. Accessible at: www.oecd.org/environment/cc/Projecting\%20Climate\%20Change\%202020\%20WEB.pdf. [Accessed 10 January 2017].

O’Rourke, H. (2015). COP21 By The Numbers. Politico.edu. 11 November. Available at: www.politico.eu/article/cop21-by-numbers/. [Accessed 23 January 2017].

O'Sullivan, A. and Sheffrin, S.M. (2003). Economics: Principles in Action. Upper Saddle River, New Jersey 07458: Pearson Prentice Hall. p. 471.

Quinn, E. (2015). Arctic Missing from Paris Climate Agreement. Radio Canada International. 18 December. Available at: http://www.rcinet.ca/en/2015/12/18/arcticmissing-from-paris-climate-agreement/. [Accessed 10 January 2017]. 
Paris Agreement - Status of Ratification. United Nations Framework Convention on Climate Change. Available at: unfccc.int/paris_agreement/items/9444.php [Accessed January 10, 2017].

Roshanafshar, S. and Hawkins, E. (2015). Food Insecurity in Canada, Statistics Canada. Ministry of Industry. 25 March. Available at: www.statcan.gc.ca/pub/82-624x/2015001/article/14138-eng.pdf [Accessed 2 January 2017].

Statistics Canada. (2015). Infant Mortality Rates, by province and territory (Both sexes). Statistics Canada. Available at: www.statcan.gc.ca/tables-tableaux/sumsom/101/cst01/health21a-eng.htm [Accessed 2 January 2017].

Thornton, T.F. (2012). Being and place among the Tlingit. City Published: University of Washington Press.

Tennberg, M. (2010). Indigenous peoples as international political actors: a summary. Polar Record, vol. 46(03), pp. 264-270.

United Nations Framework Convention on Climate Change. (2015). Adoption of the Paris Agreement, 21st Conference of the Parties. Paris: United Nations. Available at: unfccc.int/files/meetings/paris_nov_2015/application/pdf/paris_agreement_english_.pdf [Accessed 15 January 2017].

United Nations 2014, United Nations Framework Convention on Climate Change. Available at: unfccc.int/focus/climate_finance/items/7001.php [Accessed January 10, 2017].

United Nations 2017, 'Warsaw International Mechanism for Loss and Damage Associated with Climate Change Impacts', United Nations Framework Convention on Climate Change, Available at: unfccc.int/adaptation/workstreams/loss_and_damage/items/8134.php [Accessed January 10, 2017].

United Nations 2016, 'Chronology - Loss and Damage', United Nations Framework Convention on Climate Change, Available at: unfccc.int/adaptation/workstreams/loss_and_damage/items/7545.php [Accessed January 10, 2017].

United Nations 2017, Criteria for Identification and Graduation of LDCs, UN Office of the High Representative for the Least Developed Countries, Landlocked Developing Countries and Small Island Developing States, Available at: unohrlls.org/about-ldcs/criteria-for-ldcs/ [Accessed January 10, 2017].

United Nations (1992), 'United Nations framework convention on climate change'. In United Nations Framework Convention on Climate Change. Available at: unfccc.int/resource/docs/convkp/conveng.pdf [Accessed January 10, 2017].

United Nations Educational, Scientific and Cultural Organization (2016), 'UNESCO's Action in Support of Climate Change Adaptation.' Unesco.org. Available at: http://www.unesco.org/fileadmin/MULTIMEDIA/HQ/SC/pdf/AdaptationFund_04Oct2016.pdf [Accessed August 25, 2017].

Vidal, J. (2008). The Big Melt. The Guardian. 2 January; 21. 
Walker, Tasmin (12 September 2015). "Olafur Eliasson, artist, Iceland \& Minik Thorleif Rosing, scientist, Greenland," DW. Accessible at: http://www.dw.com/en/olafur-eliasson-artist-iceland-minik-thorleif-rosing-scientist-greenland/a-18904149. [Accessed August 25, 2015].

(Watt-Cloutier, S. (2004). Climate Change and Human Rights. Carnegie Council. 22 April. Accessible at: https://www.carnegiecouncil.org/publications/archive/dialogue/2_11/section_1/4445/:pf_printable/Template=print?version=1464021925. [Accessed 20 January 2017].

Wæver, O. (1993). Securitization and desecuritization. Copenhagen: Centre for Peace and Conflict Research.

Wæver, O. (2008). The changing agenda of societal security. In: Name of editor, (ed.). Globalization and Environmental Challenges. City published: Springer Berlin Heidelberg, pp. 581-593

Wilkins, R., Uppal, S., Finès, P., Senécal, S., Guimond, É. and Dion, R. (2003) Life Expectancy in the Inuit-Inhabited Areas of Canada, 1989 to 2003. Statistics Canada, Available at: www.statcan.gc.ca/pub/82-003-x/2008001/article/10463eng.htm [Accessed 2 January 2017].

World Bank Group. (2016). Countries Affirm in Closing Hours of COP22: The Adaptation Fund Should Serve the Paris Agreement. Adaptation Fund. Available at: www.adaptation-fund.org/wp-content/uploads/2016/11/Press-release11222016_Countries-Affirm-in-Closing-Hours-of-COP22-The-AdaptationFund-Should-Serve-the-Paris-Agreement.pdf [Accessed 10 January 2017]. 